\title{
Nerve conduction studies in patients with type 2 diabetes mellitus in Basrah
}

\author{
Osama K. Ibrahim1, Thamer A. Hamdan², Safaa H. Ali³, Ahmed A. Salim ${ }^{4}$
}

\section{ABSTRACT}

Background: Diabetes mellitus has an effect on the peripheral nerves. Such effect may start as asymptomatic peripheral neuropathy.

Objectives: To assess the role of electrodiagnostic study in the diagnosis of patients with different types of diabetic peripheral neuropathy (DPN) and evaluate the usefulness of it in early detecting diabetic peripheral neuropathy in asymptomatic patients and to correlate the findings of nerve conduction study in patients with asymptomatic diabetic peripheral neuropathy with various risk factors.

Subjects and Methods: subjects were allocated into three groups: 50 normal (non-diabetics apparently healthy subjects without peripheral neuropathy), 50 asymptomatic DPN patients and 50 symptomatic DPN patients. Clinical questionnaire, blood sugar, neurological examination and nerve conduction studies were performed for each subject.

Results: This study showed that the prevalence of positive nerve conduction studies was $58 \%$ in asymptomatic diabetic patients, $\mathbf{1 0 0 \%}$ for symptomatic diabetic patients and negative for control. The positive nerve conduction study findings in asymptomatic diabetic patients involved sensory more than motor fibers and the lower limbs nerves were affected more than that of the upper limbs. The most commonly involved nerve is the sural nerve sensory fiber which was more prevalent in old age patients (87.5\%), patients with longer duration of diabetes $(81.8 \%)$, over weight $(\mathbf{7 1 . 4 \%})$, patient taking only oral antihyperglycemic drugs (76.9\%) and in diabetic patients with poor glycemic control $(\mathbf{8 4 . 2 \%})(\mathbf{8 6 . 3 \%})$ in fasting blood glucose (FBG) and HbAlc respectively. Using the logistic regression, only oral antihyperglycemic drugs (without insulin) and poor control HbAlc were significant predictors of abnormal nerve conduction.

Conclusion: Even in asymptomatic patients, nerve conduction studies show diffuse changes, in a predictable pattern. Electrophysiological finding correlate with age, duration of disease, glycosylated hemoglobin levels, fasting blood glucose, type of the treatment if only oral antidiabetic and body mass index.

Keywords: diabetes, asymptomatic, peripheral, neuropathy.

$$
\begin{aligned}
& \text { دراسة تخطيط الأعصاب لمرضى داء السكري نوع r } \\
& \text { خلفية الدراسة: مرض داء السكري له تأثير على الأعصاب المخيطة وقسم منها يبدأ بدون أعراض اعتلال الأعصاب المحيطة. } \\
& \text { الهدف من الدراسة: تقييم دور وجدوى تخطيط الأعصاب في مختلف أنواع اعتلال الأعصاب المخيطة السكري الكشف المبكر عن اعتلال } \\
& \text { الأعصاب المحيطية السكري في المريض بدون أعراض سريريه و ارتباط نتائج تخطيط الأعصاب لمرضى السكري بدون أعراض سريريه مع } \\
& \text { عوامل المؤثرة الأخرى. } \\
& \text { الطريقة والمواد: العينات صنفت بثلاث بجاميع على الشكل التالي: .0 شخص من الأصحاء ليس لديهم داء سكري و لا أعراض } \\
& \text { اعتلال الأعصاب المحيطة، و ـ0 شخص لديهم داء السكري نوع ب وليس لديهم علامات اعتلال الأعصاب المخيطة و .0 شخص لديهم }
\end{aligned}
$$

\footnotetext{
${ }^{1} \mathrm{MBChB}, \mathrm{MSC}$ physiology candidate

${ }^{2} \mathrm{MBChB}$, FRCS FACS, Orthopedic Surgeon

${ }^{3} \mathrm{MBChB}$, PhD Physiology, American Board of Electrodiagnostic Medicine.

${ }^{4} \mathrm{MBChB}$, FICMS-Neuro-Medicine
} 


$$
\begin{aligned}
& \text { مرض داء السكري و علامات اعتلال الأعصاب المحيطة. وقد خضعوا جميعهم إلى الاستبيان السريري وفحص السكر بالدم وفحص } \\
& \text { الأعصاب ألسريري و أجرى عليهم الاستقصاءات الكهروفسيولوجية لتخطيط الأعصاب المحيطة الكهربائي. } \\
& \text { النتائج: وبينت هذه الدراسة أن معدل انتشار الاستقصاءات الكهروفسيولوجية لتخطيط الأعصاب المخيطة الكهربائي إيجابية } \\
& \text { ^هـللمرضى السكري الذين ليس لديهم أعراض اعتلال الأعصاب الخميطة و كانت . . 1\% للذين لديهم إعراض و كانت نتيجة سلبية } \\
& \text { للأصحاء، وكان هذا الاعتلال العصبي المحيطي السكري لفئة مرضى السكري من غير أعراض وعند تقييم الأعصاب الحسية يظهر تدهورا } \\
& \text { ملحوظا في كفاءما أكثر من الأعصاب الحركية و أعصاب الأطراف السفلى أكثر من الأطراف العليا ويعد العصب الربلي الحسي أكثر }
\end{aligned}
$$

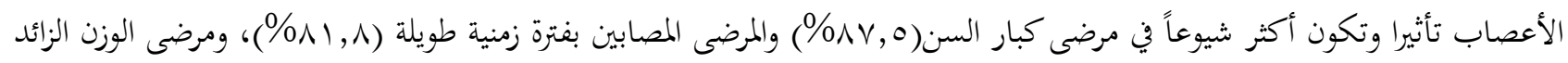

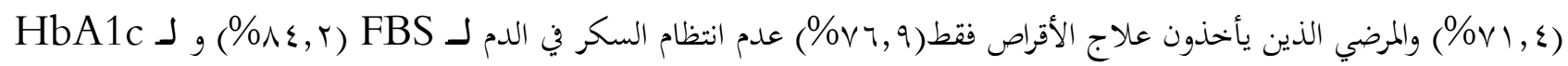

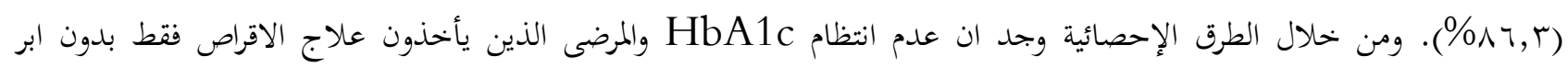

$$
\begin{aligned}
& \text { الانسولين اكثر حلات تنبئا بوجود نتائج ايجابية في تخطيط الاعصاب. } \\
& \text { الاستنتاج: قسم من المرضى من غير أعراض سريرية لعتلال الأعصاب المحيطة السكري يكون لديهم نتائج ايجابية عند أجراء تخطيط } \\
& \text { الأعصاب لهم وهذه النتائج ترتبط طرديا مع زيادة في العمر و طول فترة الإصابة بالمرض وعدم انتظام السكر بالدم و نوع العلاج إذا كانوا } \\
& \text { يأخذون أقراص فقط و زيادة مؤشر كتلة الجسم. } \\
& \text { الكلمات المفتاحية: السكري، عديم الاعراض، محيطي، ضعف الاعصاب }
\end{aligned}
$$

\section{INTRODUCTION}

$\mathrm{D}$ iabetic peripheral neuropathy (DPN) is a descriptive term meaning a demonstrable disorder, either clinically evident or subclinical, that occurs in diabetes mellitus without other causes of peripheral neuropathy. About 60 to $70 \%$ of people with diabetes have some form of neuropathy. ${ }^{[1,2]}$ Impairment of sensory motor axons and myelin sheath at the distal nerve ending already exists in early stages of diabetic peripheral neuropathy. Before symptoms arise electrophysiological test reveals impairment of peripheral nerves. ${ }^{[3]}$ If the neuropathy is sensory, symptom as tingling, numbness, loss pain and loss temperature sensation are the main manifestations, while if the neuropathy is motor, then symptom as muscle weakness, wasting and paralysis are evident. ${ }^{[4]}$ The mechanism of the DPN depend on how long exposure to high blood glucose, the mechanism either due to increase polyol flux leading to neuron cell lysis ${ }^{[5]}$ or due to advanced glycation end products (AGE) of vessel wall that activate inflammatory cascades, resulting in neural ischemia and cell damage and death. ${ }^{[6,7]}$ also may be due to decreased effectiveness of the Vascular Endothelial Growth Factor. ${ }^{[8]}$

\section{Electro diagnostic test (EDX):}

Electrophysiological study of the peripheral nervous system is highly sensitive for defining the pattern and degree of nerve involvement and chronicity of a neuropathy. It is considered an extension of the neurological examination supplementing the clinical examination by providing additional precision, details, objectivity and delineate a variety of pathological changes that are clinically either obscure or undetectable. The Electromyography evaluation includes nerve conduction studies (sensory and motor) and the needle electromyographic examination of muscle. ${ }^{[5]}$ The important electrodiagnostic test for early diagnosis of DPN by localization of lesion, distribution lesion, type of pathology, state the severity of the disease process and assessment 
of prognosis and the effect of treatments. The present study was designed to assess the role of electrodiagnostic study in the diagnosis of patients with different types of diabetic peripheral neuropathy and to evaluate the usefulness of it in early detecting diabetic peripheral neuropathy in asymptomatic patients and to correlate the findings of nerve conduction study in patients with asymptomatic diabetic peripheral neuropathy with various risk factors.

\section{SUBJECT AND METHODS}

This cross sectional study was conducted at the College of Medicine, University of Basrah during the academic year 2016/2017 and was approved by the College Ethical Committee. Three groups of human subjects were included in this study collects from Al-Faiha Specialized Diabetes, Endocrine, and Metabolism Center (FDEMC) in AL-Faiha hospital and neuromedicine outpatient department in ALBasrah General hospital. Electromyographic tests were carried on the three groups, the controls, asymptomatic DPN patients and symptomatic DPN patients. All of them were informed regarding the technique of the test and the aim of the study, and their consent was taken. Nerve conduction studies were performed on both upper and lower limbs. A detailed questionnaire was filled for each subject which included personal characteristics, family history, duration of disease, type of treatment, anthropometric measures, physical examination, biochemical measurements including fasting plasma glucose, post prandial plasma glucose and $\mathrm{HbA} 1 \mathrm{c}$, excluded anypatients had another type of peripheral neuropathy rather than diabetic peripheral neuropathy.

Electro diagnostic evaluation: Electro diagnostic examination included two components: Nerve Conduction Studies (NCS) and the needle electromyographic (EMG) study, were done at room temperature $25^{\circ} \mathrm{C}$ with MICROMED, KP $3.0{ }^{\circledR}$ model 2003 using surface electrodes and needle electrodes performed by single investigator. It was done using conventional method with limbs kept warm, in (DM) patients and the control group were also measured. ${ }^{[9]}$

Nerve Conduction Studies: The distal sensory latency (DSL), sensory conduction velocity (SCV) and sensory amplitude (Amp) were measured for median, ulnar and sural nerves as well as distal motor latency (DML), motor conduction velocity (MCV), motor amplitude (Amp) were measured for median, ulnar and common peronal nerve. F-wave for right common peronal nerve and right ulnar nerve, $\mathrm{H}$ reflex for right and left posterior tibial nerves.

Needle-Electromyography: The electrical motor unit recorded by the EMG needle is called the motor unit action potential (MUAP) and represents only a portion of the anatomic motor unit. It was done only for asymptomatic \& symptomatic diabetic patient only, \& choice 3 muscles: right first dorsal interosseous as upper limb muscles. left extensor digitorum brevis and right tibialis anterior as lower limb muscles.

\section{Staged severity of various types of DPN according to electrodiagnostic studies:[10]}

1. Early stage of neuropathy if H-reflex is low or not present.

2. Mild axonal sensory neuropathy if sensory nerve action potential amplitude (SNAP) is reduced.

3. Mild axonal sensorimotor neuropathy if sensory nerve action potential and compound muscle action potential (CMAP) were reduced.

4. Moderate axonal sensorimotor neuropathy if associated with delay latencies in addition to sensory nerve action potential and compound muscle action potential were reduced.

5 . When the amplitude of the motor response are significantly involved with needle EMG changes of axonal degeneration or we don't obtained motor response we considered as advanced.

6. demyelinating neuropathy when nerve conduction velocity Decline more than $70 \%$ of the normal value. 


\section{RESULTS}

\section{Characteristics of the study population}

There are no statistically significant differences between the various characteristics of subjects recruited for the 3 groups; control group, asymptomatic and symptomatic diabetic groups in terms of age, gender, height, weight, body mass index and family history education level while significant in term of $\mathrm{HbA} 1 \mathrm{c}$, fasting blood glucose, type of treatment, duration and Associated diseases (Tables-1).

Table 1. Characteristics of the study population.

\begin{tabular}{|c|c|c|c|c|}
\hline Parameters & $\begin{array}{c}\text { People with } \\
\text { no diabetes } \\
n=50\end{array}$ & $\begin{array}{l}\text { Patients with no } \\
\text { symptoms of PNP* } \\
n=50\end{array}$ & $\begin{array}{l}\text { Patients with symptoms } \\
\text { of PNP* } \\
n=50\end{array}$ & P Value \\
\hline Age in years mean \pm SD & $52 \pm 7.6$ & $54.6 \pm 9.2$ & $55.12 \pm 9.5$ & 0.328 \\
\hline $\begin{array}{c}\text { Gender }=\mathbf{n}(\%) \\
\text { Males } \\
\text { Females }\end{array}$ & $\begin{array}{l}34(68 \%) \\
16(32 \%)\end{array}$ & $\begin{array}{l}30(60 \%) \\
20(40 \%)\end{array}$ & $\begin{array}{l}28(56 \%) \\
22(44 \%)\end{array}$ & 0.898 \\
\hline $\begin{array}{c}\text { Education }=\mathrm{n}(\%) \\
\text { Illiterate } \\
\text { Primary school** } \\
\text { Secondary school } \\
\text { Basic university \& Higher } \\
\text { education }\end{array}$ & $\begin{array}{cc}9 & (18 \%) \\
15 & (30 \%) \\
14 & (28 \%) \\
12 & (24 \%)\end{array}$ & $\begin{array}{c}10(20 \%) \\
18(28 \%) \\
14(36 \%) \\
8(16 \%)\end{array}$ & $\begin{array}{c}15(30 \%) \\
19(38 \%) \\
11(22 \%) \\
5(10 \%)\end{array}$ & 0.06 \\
\hline Height in $\mathrm{cm}$ mean \pm SD & $169.89 \pm 6.6$ & $168.8 \pm 6.3$ & $168.1 \pm 7.4$ & 0.638 \\
\hline Weight in Kg mean \pm SD & $67.93 \pm 8.6$ & $68.98 \pm 16.3$ & $68.12 \pm 15.21$ & 0.906 \\
\hline Body mass index in $\mathrm{Kg} / \mathrm{m}^{2}$ mean $\pm \mathrm{SD}$ & $23.46 \pm 2.1$ & $24 \pm 4.8$ & $23.92 \pm 4.2$ & 0.765 \\
\hline $\begin{array}{c}\text { Associated diseases }=\mathrm{n}(\%) \\
\text { NO associated disease } \\
\text { Hypertension } \\
\text { Ischemic heart disease } \\
\text { Sickle cell anemia } \\
\text { HT and IHD } \\
\text { HT and SCA }\end{array}$ & & $\begin{array}{c}27(54 \%) \\
14(28 \%) \\
3(6 \%) \\
4(8 \%) \\
1(2 \%) \\
1(2 \%)\end{array}$ & $\begin{array}{c}17(34 \%) \\
17(34 \%) \\
4(8 \%) \\
7(14 \%) \\
3(6 \%) \\
2(4 \%)\end{array}$ & $<0.001$ \\
\hline $\begin{array}{c}\text { Type of treatments = n(\%) } \\
\text { Oral antihyperglycemic } \\
\text { Oral + Insulin }\end{array}$ & & $\begin{array}{c}43(86 \%) \\
7(14 \%)\end{array}$ & $\begin{array}{l}38(76 \%) \\
12(24 \%)\end{array}$ & $<0.001$ \\
\hline $\begin{array}{c}\text { Fasting blood glucose in } \\
\mathrm{mg} / \mathrm{dl} \\
\text { Controlled }=\mathrm{n}(\%) \\
\text { Accepted }=\mathrm{n}(\%) \\
\text { Poor }=(\%)\end{array}$ & $\begin{array}{c}93.65 \pm 9 \\
(80-116) \\
50(100) \\
0 \\
0\end{array}$ & $\begin{array}{c}151.9 \pm 16 \\
(130-184) \\
0 \\
31(62) \\
19(38)\end{array}$ & $\begin{array}{c}167.22 \pm 38.7 \\
(133-320) \\
0 \\
27(54) \\
23(46)\end{array}$ & $<0.001$ \\
\hline $\begin{array}{c}\text { HbA1c \% mean } \pm \text { SD } \\
\text { Controlled }=n(\%) \\
\text { Accepted }=n(\%) \\
\text { Poor }=(\%)\end{array}$ & $\begin{array}{c}5.48 \pm 0.29 \% \\
(4.7-6.3) \\
50(100 \%) \\
0 \\
0\end{array}$ & $\begin{array}{c}8.2 \pm 1.4 \% \\
(6.1-11) \\
4(8 \%) \\
24(48 \%) \\
22(44 \%)\end{array}$ & $\begin{array}{c}9.4 \pm 1.67 \% \\
(6.8-12.7) \\
0 \\
27(54 \%) \\
23(46 \%)\end{array}$ & $<0.001$ \\
\hline Duration of D.M. in years mean \pm SD & & $6.3 \quad 3.2$ & $7.86 \pm 4.08$ & $<0.001$ \\
\hline
\end{tabular}

* PNP: Peripheral neuropathy,

** Including those who just read and write 


\section{Finding of the Nerve conduction studies}

in all groups:

The electro-diagnostic studies were positive in negative for all control group individuals, all patients in the symptomatic group and (Table-2).

$29(58 \%)$ of the asymptomatic group while

Table 2. Prevalence of positive $\&$ negative nerve conduction study for all groups.

\begin{tabular}{||c|c|c|c||}
\hline \hline Nerve conduction studies findings & $\begin{array}{c}\text { Control } \\
\text { (\%) }\end{array}$ & $\begin{array}{c}\text { Asymptomatic } \\
\text { DPN* } \\
(\%)\end{array}$ & $\begin{array}{c}\text { Symptomatic } \\
\text { DPN* } \\
\text { (\%) }\end{array}$ \\
\hline Positive & $0(0 \%)$ & $29(58 \%)$ & $50(100 \%)$ \\
\hline Negative & $50(100 \%)$ & $21(42)$ & $0(0 \%)$ \\
\hline Total & 50 & 50 & 50 \\
\hline
\end{tabular}

*DPN: diabetic peripheral neuropathy

\section{Factors predicting nerve conduction}

\section{abnormalities}

In order to identify the independent predictors conduction (Abnormal versus normal). The of nerve conduction abnormality among independent variables entered in the equation asymptomatic patients, we used logistic are shown in (Table-3). Only two variable could regression analysis as shown in (Table-3). The predict nerve conduction abnormality these are dependent variable was the state of nerve type of treatment and HbA1c.

Table 3. Logistic regression analysis to predict nerve conduction study among asymptomatic patient.

\begin{tabular}{||c|c|c|c|c|c||}
\hline \multirow{2}{*}{ Independent variables } & \multirow{2}{*}{ B } & P value & $\begin{array}{c}\text { Or } \\
\text { (exp) }\end{array}$ & \multicolumn{2}{|c|}{ Confidence limit } \\
\cline { 5 - 6 } & & & & Lower & Upper \\
\hline Significant predictors & & & & & \\
Type of treatment (Mixed) & 2.110 & 0.008 & 8.249 & 1.715 & 39.679 \\
HbA1c & 1.123 & 0.031 & 0.325 & 0.118 & 0.901 \\
\hline Age & & & & & \\
Gender & 0.008 & 0.913 & 0.992 & 0.857 & 1.148 \\
BMI & 1.279 & 0.213 & 3.594 & 0.48 & 26.925 \\
Duration & 0.097 & 0.29 & 0.907 & 0.757 & 1.086 \\
FBS & 0.231 & 0.252 & 0.794 & 0.535 & 1.178 \\
\hline
\end{tabular}


Abnormal electrodiagnostic findings in asymptomatic and symptomatic DPN

Distribution of diabetic peripheral neuropathy with abnormal nerve conduction finding in 29

asymptomatic DPN and 50 symptomatic DPN (Table-4).

Table 4. Distribution abnormal nerve conduction studies according to nerves.

\begin{tabular}{||c|c|c||}
\hline Abnormal nerve parameters & Asymptomatic dpn & Symptomatic dpn \\
\hline H reflex & $5(17.2 \%)$ & $3(6 \%)$ \\
\hline H reflex-sural & $10(34.4 \%)$ & $15(30 \%)$ \\
\hline H reflex sural-peroneal & $4(13.8 \%)$ & $7(14 \%)$ \\
\hline $\begin{array}{c}\text { H reflex Sural Peroneal median(M*\&**) } \\
\text { ulnar (M\&S) }\end{array}$ & $4(13.8 \%)$ & $9(18 \%)$ \\
\hline H reflex- Sural Peroneal- median (M\&S)- & $1(3.4 \%)$ & \\
\hline $\begin{array}{c}\text { ulnar (S) } \\
\text { H reflex peroneal median (S) ulnar(S) }\end{array}$ & $5(17.2 \%)$ & $1(2 \%)$ \\
\hline H reflex peroneal ulnar (M\&S) & & $7(14 \%)$ \\
\hline H reflex median (M\&S) ulnar (M\&S) & & \\
\hline
\end{tabular}

DPN: diabetic peripheral neuropathy, ${ }^{*} \mathrm{M}:$ motor, ${ }^{* *}$ : sensory

$H$ reflex (right and left tibial nerve) is prolong or absent in all positive nerve conduction studies.

\section{Incidence and severity of the abnormal}

electro diagnostic findings

Regarding asymptomatic diabetic peripheral neuropathy including early stage of neuropathy in $5(17.2 \%)$ patients, mild sensory axonal neuropathy in $10(34.5 \%)$ patients, mild sensorimotor axonal neuropathy in $8(27.5 \%)$ patients, moderate sensorimotor axonal neuropathy in $6(20.6 \%)$ patients while in symptomatic diabetic peripheral neuropathy including early stage in $3(3 \%)$ patients, mild sensory axonal neuropathy in $15(30 \%)$ patients, mild sensorimotor axonal neuropathy in $11(22 \%)$ patients, moderate sensorimotor axonal neuropathy in 19(38\%) patients and advance sensory motor axonal neuropathy in $2(4 \%)$ patients (Table-5) 
Table 5. Incidence and severity of the abnormal electrodiagnostic findings.

\begin{tabular}{||l|c|c||}
\hline Severity & $\begin{array}{c}\text { Asymptomatic* } \\
\text { DPN (N=29) (\%) }\end{array}$ & $\begin{array}{c}\text { Symptomatic* } \\
\text { DPN ( N=50)(\%) }\end{array}$ \\
\hline Early & $5(17.2 \%)$ & $3(6 \%)$ \\
\hline Mild sensory axonal neuropathy & $10(34.5 \%)$ & $15(30 \%)$ \\
\hline Mild sensorimotor axonal neuropathy & $8(27.5 \%)$ & $11(22 \%)$ \\
\hline Moderate sensorimotor axonal neuropathy & $6(20.6 \%)$ & $19(38 \%)$ \\
\hline Advance & $0(0 \%)$ & $2(4 \%)$ \\
\hline
\end{tabular}

*Data are presented as the number of patients with abnormal electrodiagnostic findings (\%).

\section{DISCUSSION}

DPN is a common microvascular complication of diabetes mellitus that eventually affects the majority of diabetic patients. Symptoms may develop at any degree of neuropathic impairment or may not. Nerve conduction studies had been proved to be the more powerful indicator for neuropathy than clinical examination especially in the asymptomatic groups. $^{[11]}$ Its worldwide prevalence seems significant and is associated with significant morbidity and disability. ${ }^{[12]}$ In our study the prevalence of neuropathy in asymptomatic diabetic peripheral neuropathy according to NCS finding was $58 \%$, while in Kjersti, et al study in Bangladesh they reported an overall prevalence of DPN of $19.7 \%,{ }^{[13]}$ Uwakwe et al study in Nigeria found a prevalence rate of DPN is $75 \%$. ${ }^{[1]}$ In Rochester DPN study neuropathy presented in $66 \%$ of diabetic patients. ${ }^{[15]}$ While in Khaled et al in Egypt the prevalence of DPN among studied subjects was $29.7 \% .^{[16]}$ The differences in prevalence of DPN among different countries may be attributed to methodological differences in diagnosing DPN, ethnic differences in the prevalence of DPN attributed to different exposure to risk factors of DPN and different patients. In our study only two variables could predict nerve conduction abnormality, these are HbA1c level and type of treatment. Significant association between poor glycemic control and the development of DPN in aymptomatic group had been found and $86.3 \%$ of asymptomatic patients had been found to have high $\mathrm{Hb} \mathrm{A} 1 \mathrm{c}$ level. This agrees with Arindam study ${ }^{[17]}$ where prolonged and poorly controlled DM was the most significant factors associated with DPN. Also Kaur study in India had found that maintenance of aggressive control of HbAlc is the key to prevent and delay the DPN. ${ }^{[18]}$ The association between poor glycemic control and the development of DPN can be explained by the well-known harmful metabolic, inflammatory and oxidative effects of hyperglycemia on the nerves fiber beside the damages to small blood vessels (micoangiopathy) which lead to nerve fibers damage. ${ }^{[19]}$ Also in our study, significant association between type of treatment and the development of DPN in asymptomatic group had been found and $76.9 \%$ of asymptomatic patients who take only oral antidhyperglycemic drugs had been found to have DPN in compare to $37.5 \%$ of asymptomatic patients who take mixed treatment with Insulin \& oral antidhyperglycemic drugs which is consistent other studies. ${ }^{[20]}$ In our study the most common changes on nerve conduction study in both asymptomatic and symptomatic diabetic peripheral neuropathy groups were abnormality of $\mathrm{H}$ - reflex and sural nerve. Regarding the severity of nerve conduction studies, mild sensory axonal neuropathy were the most 
common in asymptomatic diabetic peripheral neuropathy group followed by mild sensori motor axonal neuropathy while in symptomatic diabetic peripheral neuropathy group moderate sensori- motor axonal neuropathy were the most common followed by mild sensorimotor axonal neuropathy, this may indicate that peripheral neuropathy start early with sensory changes then with the chronicity of the disease, motor nerves involve. In both groups the nerve conduction studies abnormalities in lower limbs were more common than upper limbs, the Fwave was intact for all patients while the $\mathrm{H}$ reflex was unobtainable or prolonged in all patients with peripheral neuropathy. These findings are consistent with study by Rainha J. de souza et $\mathrm{al}^{[21]}$ and Misra et $\mathrm{al}^{[22]}$ which show similar findings in their study. This can be explained by the fact that diabetic peripheral neuropathy is a type of metabolic neuropathy and the pattern of this neuropathy is usually length depended peripheral neuropathy and it is usually start in the lower limb and then ascend up to involve the upper limbs and also it is usually involve first the sensory nerves and then involve the motor nerves which is in agreement with the findings obtained by our study.

In conclusions, the risk of developing peripheral neuropathy in asymptomatic diabetic patients is fairly high and significantly related to glycemic control. Absence of symptoms didn't exclude DPN and a significant proportions of those patients were in danger of developing foot ulcers.

\section{REFERENCE}

1. Ozougwu JC, Obimba KC, Belonwu CD. The pathogenesis and pathophysiology of type 1 and type 2 diabetes mellitus. Journal Physiology and Pathology 2013; 4: 46-57.

2. Prestone DC, Shapiro B E. Electromyography Neuromuscular Disorders. Ohio.:Elsevier Inc, 2013: 21-26 and 386 - 390.

3. Aruna BM, Haragopa R. Role of Electrodiagnostic Nerve Conduction Studies in the Early Diagnosis of Diabetic Neuropathy: A
Case-Control Study. International Journal of Scientific Study2016; 4: 54-68.

4. Vinik AI. Diabetic Sensory and Motor Neuropathy. The New England Journal of Medicine 2016; 374:1455-1464.

5. Jun K. Electrodiagnosis in Diseases of Nerve and Muscle. $4^{\text {th }}$ ed. New York: Oxford University Press, 2013.

6. Jack MM, Wright DE. The Role of Advanced Glycation Endproducts and Glyoxalase $I$ in Diabetic Peripheral Sensory Neuropathy. Pub med Research2012, [online] 159: 355-365. Avaliable at: http://www.ncbi.nlm.nih.gov/pubmed/22500508. Accessed on December 24,2017.

7. Costenaro F. Neuropatia Diabetica. In: Silveiro, S.P. and Satler, F. Eds., Rotinas em Endocrinologia, Chap. 4, Artmed, Porto Alegre, 2015.

8. Stoian A, Bacârea A, Moțățăianu A. Vascular Endothelial Growth Factor Insertion/ Deletion gene polymorphism in patients with type 2 diabetes and diabetic peripheral polyneuropathy . Revista Română de Medicină de Laborator 2014; 22: 165-172.

9. Qayyum A,Ghouse $R$ A.Govindarajan $R$. Neurophysiology in Clinical Practice Gewerbestrasse: Springer, 2017: 35-37,63-64, 7980.

10. Toopchizadeh V, Shiva S, Khiabani NY, Ghergherechi R. Electrophysiologic pattern and prevalence of subclinical peripheral neuropathy in children and adolescents with type I diabetes mellitus in Iran .Saudi Med J 2016; 37: 299-303.

11. Höliner I, Haslinger V, Lütschg J, et al. Validity of the neurological examination in diagnosing diabetic peripheral neuropathy. Pediatr neurol 2013; 49: 171-177.

12. Khalid K, Morsy A, Abdel Aziz E, Said Abdel Gawad. Peripheral neuropathy in type 2 diabetic patients attending diabetic clinics in $\mathrm{Al}$ - Azhar University hospital, Egypt. Int .J. of Diabetes mellitus 2010; 2: 20-30.

13. Kjersti $M$, Liaquat A, Akhtar $H$. Risk factors and prevalence of diabetic peripheral neuropathy: A study of type 2 diabetic outpatients in Bangladesh. Int J Diab 2010; 30:167-174.

14. Uwakwe JN, Odoh G, Edah JO, Enamino M, Chuhwak EK and Puepet FH. Diabetic peripheral neuropathy and its risk factors: A community based study. International Research 
Journal of Medicine and Biomedical Sciences, 2017; 2: 9-13.

15. Dyck PJ, Kratz KM. The prevalence by staged severity of various types of diabetic neuropathy, retinopathy and nephropathy in a population-based cohort: the Rochester diabetic neuropathy study. Neurology1993; 43: 817 - 824.

16. Khalid K, Morsy A, Abdel Aziz E, Said Abdel Gawad. (2010). Peripheral neuropathy in type 2 diabetic patients attending diabetic clinics in Al-Azhar University hospital, Egypt. Int .J. of Diabetes mellitus 2010; 2(1): 20-30.

17. Arindam D, Santa N. Prevalence of peripheral neuropathy in newly diagnosed type 2 diabetics. Int.J.Diab. Developing count 2005; 25:76-79.

18. Jaspinder Kaur. An Overview of Diabetic Neuropathy. Annual Review \& Research in Biology 2013; 3: 994-1012.
19.UK Prospective Diabetes Study Group. Intensive blood glucose control with sulphonylureas or insulin compared with conventional treatment and risk of complications in patients with type 2 diabetes. Lancet 1998; 352: 837 - 853.

20. Alahmari SD, Asiri F. Pharmacological and Nonpharmacological therapies in the Management of Diabetic Peripheral Neuropathy in Type 2 Diabetes: A Comprehensive Review. Journal of Cardiovascular Disease Research 2014; 5: 37-48.

21. Souza RJ, Aaron DS, Nagvekar MD. Nerve conduction studies in diabetics presymptomatic and symptomatic for diabetic polyneuropathy,Journal of diabetes and Its complications2015; 29: 811-817.

22. Misra UK, Kalita, J. Clinical neurophysiology (2nd ed.). New Delhi: B I Churchill Livingstone, 2006. 